\title{
Have Human Impacts Changed Alpine Zooplankton Diversity over the Past 100 Years?*
}

\author{
Monika Winder, \\ Michael T. Monaghan, \\ and Piet Spaak
}

- Department of Limnology, Swiss Federal Institute of Environmental Science and Technology (EAWAG/ ETH), Uberlandstrasse 133, PO Box 611. CH-8600 Dúbendorf, Switzerland. winder@eawag.ch

\begin{abstract}
Anthropogenic stress and fish introduction generally are thought to have elimi. nated vulnerable and sensitive zooplankton species from many alpine lakes, cre. ating impoverished communities. To investigate this hypothesis we resamplecl. lakes studied in the early 20th century and compared past and present zooplanktor composition and taxa richness. We also studied how human induced changes may influence genetic diversity of present-day populations of the widespread cladoc. eran, Daphnia. Resampling did not show a drastic overall change in planktonis: crustacean composition. Taxa richness significantly decreased with increasing lake. altitude, but no other environmental factor correlated with richness. Large zoo. plankton taxa were found in lakes both with and without fish. Therefore we conclude that the presence of fish can be excluded as the general factor explaining the occurrence or absence of large zooplankton in alpine lakes. Levels of chlo. rophyll $a$ and POC best distinguished lakes with Daphnia from lakes withoul Daphnia. In 8 out of 12 lakes sexual Daphnia were more abundant than asexual individuals. Clonal diversity ranged from 0.01 to 1.3 but was not related to the proportion of sexual individuals. The ability to create resting stages may be an essential factor for the maintenance of genetic diversity and the long-term persistence of Daphnia and other zooplankton taxa.
\end{abstract}

\section{Introduction}

In the late 19th and early 20th century, many high-altitude lakes in the European Alps were characterized and their plankton fauna and flora described in detail (e.g., Zschokke, 1900, 1908; Stingelin, 1904, 1910; Kreis, 1921; Pesta, 1929). The most frequently observed zooplankton representatives were the rotifers Notholca longispina, Keratella cochlearis, and Polyarthra platyptera. The cladoceran Daphnia longispina and copepods $C y$ clops abyssorum, Arctodiapromus alpinus, and Acanthodiapto. mus denticornis also were common. Abundant zooplankton communities were observed up to $2780 \mathrm{~m}$ a.s.l. (Zschokke, 1900; Kreis, 1921). Zschokke (1900) observed no relationship between species richness and altitude but found that lakes located in granitic catchments generally had a more diverse aquatic fauna than lakes located in calcareous catchments. The physical characteristics of lakes (e.g., temperature, duration of winter ice cover, habitat structure) were even more important in determining the aquatic fauna present than water chemistry (e.g., calcareous content).

Recent studies in the Tatra Mountains, European Alps, and Colorado Rockies indicate that plankton species composition may be changing in alpine lakes (Lieberman, 1993; Cammarano and Manca, 1997; Medina-Sánchez et al., 1999; Straskrabová et al., 1999). These studies report an impoverished fauna consisting mainly of small copepods and rotifers. Alpine regions have been increasingly altered since the late 19 th century by tourism, farming, recreation, and the development of hydropower facilities

*A version of this paper was presented at the symposium "Highmountain Lakes and Streams: Indicators of a Changing World," 48 September 2000, Innsbruck, Austria.
(CIPRA, 1998) and the consequences for alpine lakes include the introduction of fishes, eutrophication, and lake retention times changed by repeated flushing and filling of reservoirs. Fish introduction, which has occurred in Swiss Alpine lakes since the 16th century (Müller, pers. comm., 2000), has been implicated as the major biotic factor contributing to impoverished plankton communities, including local extinctions of most large-bodied cladoceran and copepod species (Gliwicz, 1985). Acidification of alpine lakes located in poorly buffered granitic catchments also may cause local extinction of sensitive zooplankton species (Cammarano and Manca, 1997). The first goal of the present study was to examine how such human influence may have changed zooplankton diversity in alpine lakes.

Genetic diversity within and among species is an important component of zooplankton diversity. Just as species diversity typically decreases at high altitude and latitude (Rosenzweig, 1995), the same has been assumed to be true for genetic diversity within species (Hedrick, 1986). For the widespread and abundant genus Daphnia, the presence of hybrids results in species complexes in which species diversity and genetic diversity overlap (Schwenk and Spaak, 1995). Therefore, Daphnia are ideal organisms to study processes responsible for patterns and changes in both species diversity and genetic diversity. Their presence in alpine lakes allows for an investigation of how human activities may impact species and genetic diversity in the alpine environment.

The second part of our study addressed how factors related to human impact may influence genetic diversity of Daphnia in alpine lakes. The reproductive biology of Daphnia suggests that different processes may influence genetic diversity at different times of the year. Daphnia reproduce by cyclic parthenogenesis. During the sexual phase, diapausing eggs encased in a resistant 


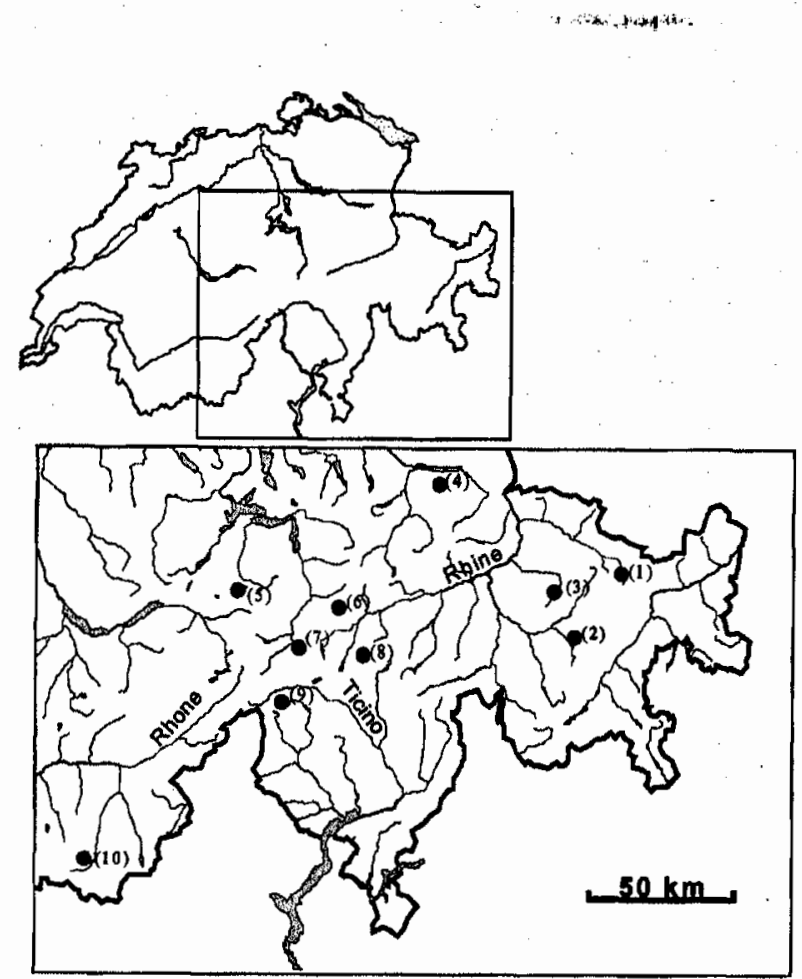

FIGURE 1. Map of the study region in Switzerland showing the locations of the lakes (dots: see Appendix 1 for names and altitudes).

structure (termed an ephippium) are produced. These ephippia sink to the sediment and may hatch in the future when environmental conditions change (Banta and Brown, 1929). In lakes and ponds where sexual reproduction occurs regularly, genetic diversity is expected to be higher compared to those lakes where daphnids overwinter as parthenogenetic females (Hebert, 1974).

This study consisted of two parts. We first examined the hypothesis that species diversity in zooplankton communities has been reduced in alpine lakes during the last $100 \mathrm{yr}$. We resampled 11 Swiss Alpine lakes in 1998, 1999, or 2000 for which historic data were available from approximately $100 \mathrm{yr}$ ago. To infer mechanisms responsible for species changes, we sampled 15 additional lakes with different levels of human impact and sought to determine the primary factors determining zooplankton richness in alpine lakes. The second part of our study concentrated on factors that influence the presence and absence of Daphnia and on factors influencing the present-day genetic diversity of populations. We hypothesized that genetic diversity would be higher in high-altitude lakes as a result of there being more sexually reproducing individuals in more harsh conditions. Further, we hypothesized inbreeding would be greater in lakes with a lower proportion of sexual individuals. Among years, we predicted that genetic turnover might be greater in lakes with more sexually reproducing individuals because of increased production of ephippia.

\section{Study Sites}

The study was conducted in 26 lakes (above $1600 \mathrm{~m}$ ) located in the Swiss Alps (see Fig. 1 for locations and Appendix 1 for physical and chemical characteristics). Eleven of the lakes were chosen because data from the beginning of the 20th century were available. Four of the lakes contained no fish (Alteinsee, Prätschsee, Oberaarsee, Riffelsee II) and the remaining lakes had fish populations. We assume that fish occur naturally in some of the lakes (Oberer Arosasee, Unterer Arosasee, Cadagno). We assume fish have been introduced to the remaining lakes because of their physical isolation (Table 1). Regardless, all lakes currently are stocked with brown trout (Salmo trutta), charr (Salvelinus alpinus), or pike (Esox lucius) on a regular basis. The Oberaarsee and Lake Robiei have been greatly enlarged for hydropower production and water levels have been raised by dam construction in six other lakes (names in Appendix 1).

\section{Materials and Methods}

\section{FIELD SAMPLING}

For each lake, temperature, $\mathrm{pH}$, and conductivity were measured in the field. A tube sampler was lowered into the water, stoppered, and transferred to a bottle to collect an integrated water sample that was analyzed for carbon and nutrient concentrations in the laboratory (for methods see Tockner et al., 1997). Chlorophyll $a$ was measured after extraction in $96 \%$ ethanol using HPLC.

Zooplankton were collected using either a 95- or 50- $\mu \mathrm{m}$ mesh plankton net. Simple vertical tows were taken from the deepest part of the lake to the surface. This was the same method used in the studies for which we have historical data. In four lakes (Alteinsee, Gruenseeli, Oberalppass, and Lutersee) horizontal tows were taken by retrieving plarikton nets thrown by hand from the shore. Samples were concentrated and preserved in $96 \%$ ethanol. Lakes were sampled in late summer or early autumn of 1997, 1998, 1999, or 2000. Three lakes (Oberer Arosasee, Unterer Arosasee, and Prätschsee) were sampled monthly during the open water period from 1998 to 1999. In winter 1998/ 99 and winter 1999/00, Oberer Arosasee was sampled through the ice. In lakes with Daphnia, we collected $=80$ individuals (adult females) for genetic analysis. In Cadagno and Schwarzsee this was not possible and we collected approximately 50 and 30 individuals, respectively. Daphnia were returned to the laboratory alive and stored in liquid nitrogen for later analysis.

\section{SPECIES IDENTIFICATION AND ALLOZYME ELECTROPHORESES}

Organisms were identified in the laboratory using taxonomic keys of Koste (1978), Flößner (1972), and Einsle (1993). Daphnia species were identified using morphological characteristics (Margaritora, 1983; Flößner and Kraus, 1986; Flößner, 1993). However, Daphnia taxonomy is in transition (Taylor et al., 1996; Gießler et al., 1999) and several norphological species hybridize. Hybrids often are the most abundant taxa in lakes (Schwenk and Spaak, 1995). Individual daphnids were screened for genetic variation at four polymorphic allozyme loci using the methods of Hebert and Beaton (1989). Aldehyde oxidase ( $A O$, Enzyme Commission number [EC] 1.2.3.1), Phosphoglucose isomerase (Pgi, EC 5.3.1.9), Glutamate- oxaloacetate transaminase (Got, EC 2.6.1.1), and Phosphoglucomutase (Pgm, EC 5.4.2.1) were scored for all populations.'

In brief, we use the term clone to designate distinct multilocus genotypes with the understanding that a given clone may actually represent a clonal group, which may range from one to many clonal lineages. Clonal diversity $(D)$ was calculated as the negative $\log$ of Simpson's Index $\left(D=-\log \Sigma \mathrm{p}_{i}{ }^{2}\right)$. Low values of $D$ indicate that a single clone is dominant, while high values indicate that many clones are abundant at approximately equal frequencies. An inbreeding coefficient $\left(F_{\mathrm{is}}\right)$ was calculated for each lake (population) using FSTAT v.2.9.1 (J. Goudet, Univ- 
TABLE I

Zooplankton composition and fish presence in sampling sites. An asterix (*) indicates taxa found in 1997-2000

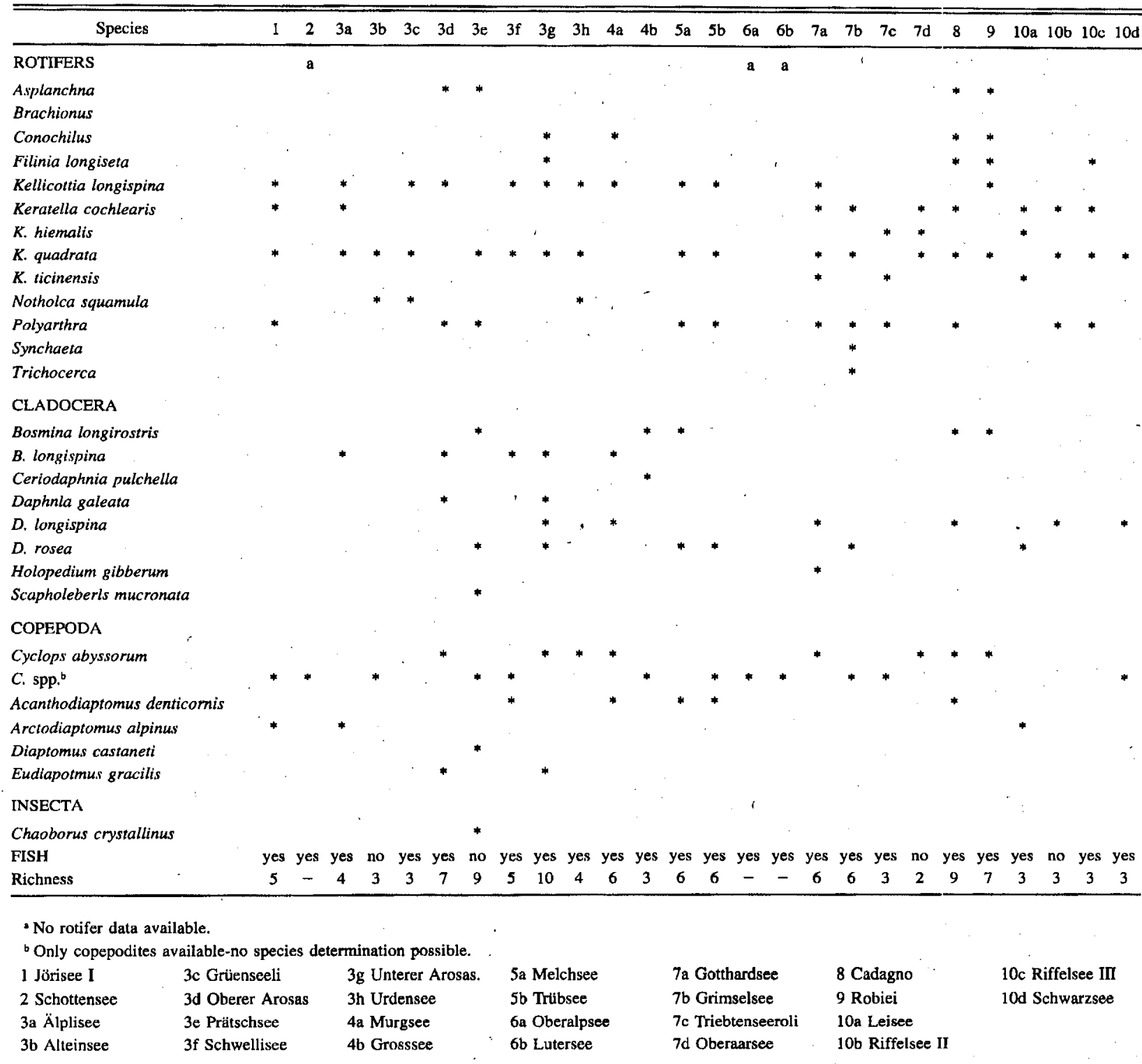

ersité de Lausanne). Heterozygote deficiency (inbreeding) in each population was tested using the score test available in GENEPOP (Raymond and Rousset, 1995). Significant positive values indicate inbreeding. To determined which loci were responsible for inbreeding values we used the probability test in GENEPOP with a Bonferroni correction (4 loci in 14 populations). In the lakes sampled monthly over two successive years, autumn samples (i.e., August, September, and October) were pooled and each year was treated as a separate population. Genetic distance (Nei, 1978) between years was calculated for each of these three lakes using BIOSYS-1 (Swofford and Selander, 1981) to examine temporal turnover in genetic structure.

Discriminant function analysis was conducted using STATISTICA to determine the lake characteristics that best predicted the presence or absence of Daphnia. All physical and chemical variables measured (in Appendix 1) were included and lakes were pre-assigned to two groups: with and without Daphnia. This resulted in a one-dimensional function analysis. Linear regression was used to investigate relationships between species or clonal diversity and environmental parameters and between proportion of sexual individuals and inbreeding. Where necessary, variables were transformed to normalize data (Sokal and Rohlf, 1995). Lakes with missing data were excluded from the analyses (see Appendix 1).

\section{Results}

\section{PRESENT-DAY SPECIES DIVERSITY}

In total, 10 rotifer genera were identified, with Keratella, Kellicottia, and Polyarthra being most widespread (Table 1). The cladoceran genus Bosmina occurred in 10 of the 26 observed lakes. Individuals of Ceriodaphnia pulchella, Holopedium gibberum, and Scapholeberis mucronata occurred only in single lakes. Among the copepods, Cyclops species, mainly $C$. abyssorum, were the most widely distributed zooplankters. The diaptomids Acanthodiaptomus denticornis and Arctodiaptomus alpinus were common. Diaptomus castaneti occurred only in 


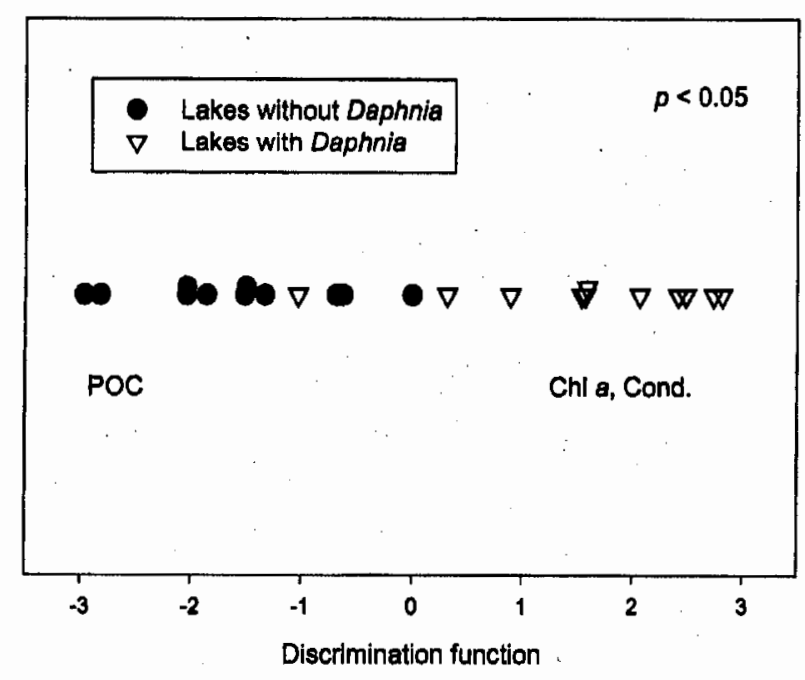

FIGURE 2. Discriminant function analysis of environmental variables (chemical and physical, see Appendix I) and lakes with Daphnia and lakes without Daphnia. Some points were moved vertically to show overlapping data points.

Prătschsee, a temporary lake, and Eudiaptomus gracilis occurred in two lakes. The Diptera predator Chaoborus crystallinus was observed in the fishless lake Prătschsee. Genera richness was significantly related to lake elevation (regression $r=-0.55, P$ $<0.01)$, but not related to DOC $(r=0.18)$, POC $(r=0.32)$, Chlorophyll $a(r=0.21)$, nitrogen $(r=0.22)$, or phosphorus $(r$ $=0.06$ ), all $P>0.05$.

Daphnia species occurred in 12 of the 26 lakes sampled. Three Daphnia species were identified and it appeared as though hybrids $(D$. longispina $\times$ hyalina) occurred in several lakes, although confirmation by use of molecular markers was beyond the scope of this study. Discriminant function analysis separated lakes with and without Daphnia (Fig. 2), marked by a negative coefficient for POC $(P=0.01)$, a positive coefficient for chlorophyll $a(P=0.02)$, and marginally $(P=0.08)$ by a positive coefficient for conductivity. Among the lakes, only Schwarzsee was grouped incorrectly (Fig. 2).

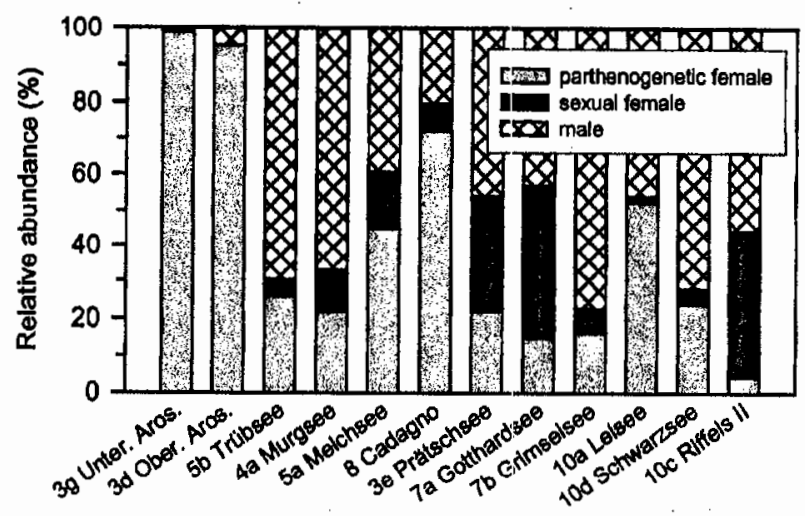

FIGURE 3. Proportion of parthenogenetic females, males, and sexual (ephippial) females of various Daphnia species in alpine lakes (for species see Table 1). Values are from autumn samples, lakes are arranged from left with increasing altitude.

\section{PAST AND PRESENT ZOOPLANKTON}

Comparison of data collected 1997-2000 with those from the early 20 th century shows both loss and gain of Cladocera and Copepoda genera in lakes (Table 2). Of the Cladocera, Daphnia has disappeared from Schottensee and Riffelsee III, while Bosmina appeared in Melchsee and Holepedium appeared in Gotthardsee. For the copepods, Cyclops and Arctodiaptomus species were not found in 3 lakes where they were reported previously. Acanthodiaptomus was not reported earlier in 2 lakes, but appeared in this study, and Eudiaptmus appeared in Oberer Arosasee (Table 2). The diversity of taxa we studied remained unchanged in 5 of the 11 lakes.

\section{SEXUAL REPRODUCTION IN DAPHNIA}

The proportion of sexual Daphnia was greater than 50\% in 8 of the 11 studied lakes (Fig. 3). The proportion of males always was higher than the proportion of sexual females (Fig. 3). Riffelsee II, Gotthardsee, and Grimselsee had the highest percentage of sexual Daphnia. Unterer Arosasee and Oberer Arosasee contained very few sexual individuals. Proportion of par-

TABLE 2

Comparison of historical and present-day studies on zooplankton composition in 11 study sites (see footnote). A minus (-) indicates that a genus disappeared, an asterix (*) indicates that a genus remained, and a plus $(+)$ indicates that a genus appeared

\begin{tabular}{|c|c|c|c|c|c|c|c|c|c|c|c|c|}
\hline Species & $1 \cdot$ & $2^{\mathrm{b}}$ & $3 d^{b}$ & $5 \mathrm{a}^{\mathrm{c}}$ & $5 b^{e}$ & $7 a^{a}$ & & $7 b^{a}$ & $10 a^{*}$ & $10 b^{a}$ & $10 c^{\mathrm{h}}$ & $10 d^{2}$ \\
\hline CLADOCERA & & & & & & & & & & & & \\
\hline Bosmina & & & $*$ & + & & & & & & & & \\
\hline Daphnia & & - & $*$ & $*$ & $m$ & $*$ & & $*$ & $*$ & $\dot{*}$ & - & * \\
\hline Holopedium & & & & & $\cdot$ & + & & & & & & \\
\hline COPEPODA & & & & & & & & & & & & \\
\hline Cyclops & $*$ & $*$ & $*$ & - & $*$ & $*$ & & * & & & - & * \\
\hline Acanthodiaptomus & & & & + & + & & & & & & & \\
\hline Arctodiaptomus & * & & & . & & & ; & - & $*$ & , & & \\
\hline Eudiapotmus & & & + & & & & & & & & & \\
\hline Richness 1900 & 2 & 2 & 3 & 2 & 2 & 3 & & 3 & 2 & 1 & 2 & 2 \\
\hline Richness 2000 & 2 & 1 & 4 & 3 & 3 & 3 & & 2 & 2 & 1 & 0 & 2 \\
\hline
\end{tabular}

Data from " Kreis (1921), 'Zschokke (1900), and 'Stingelin (1910).

$\begin{array}{llllll}1 \text { Jörisee I } & \text { 3d Obcrer Arosas. } & \text { 5b Trubsec } & \text { 7b Grimselsee } & \text { 10b Riffelsee II } & 10 \mathrm{~d} \text { Schwarzsee } \\ 2 \text { Schottensee } & \text { 5a MeIchsee } & \text { 7a Gotthardsee } & \text { 10a Leisee } & \text { 10c Riffelsee III } & \end{array}$ 


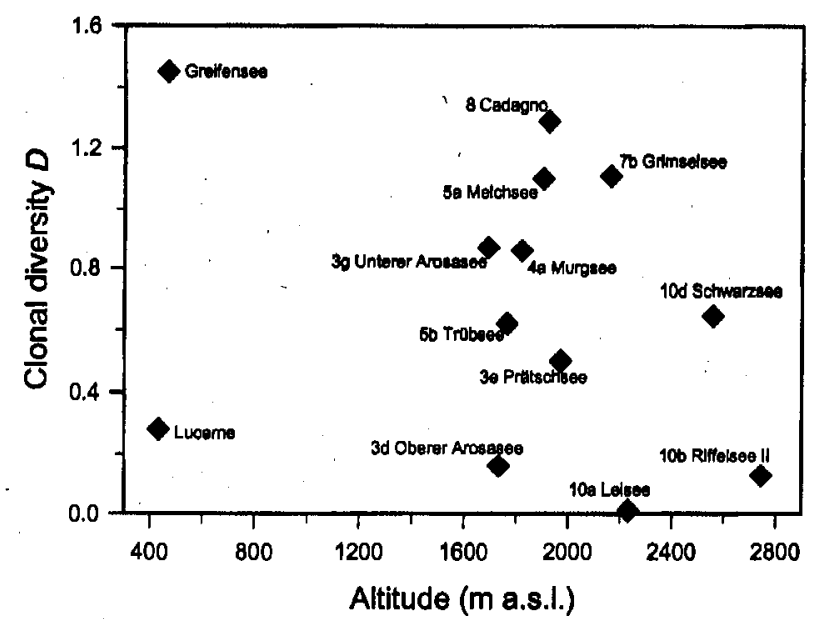

FIGURE 4. The relationship between altitude and clonal diversity $D$ of Daphnia populations in II Swiss Alpine lakes. For comparison, data on two subalpine lakes (Greifensee and Lake Lucerne, P. Spaak unpublished data) are included in the graph.

thenogenetic females was weakly negatively related to lake altitude $(r=-0.59, P=0.05)$.

\section{GENETIC DIVERSITY OF DAPHNIA}

Clonal richness (i.e., the number of unique clones per population) ranged from 2 to 54 and clonal diversity $(D)$ ranged from 0.01 to 1.3 throughout the study. Highest values were observed for $D$. longispina in Lake Cadagno and in Grimselsee (Fig. 4). Clonal diversity was unrelated to chlorophyll $a$ concentration $(r=0.30)$, POC $(r=0.45)$, and lake elevation $(r=$ -0.34). Moreover, the genetic diversity of daphnids in alpine lakes was as high as that observed in subalpine lakes (Fig. 4). Clonal diversity was unrelated to the number of sexual females, males, or parthenogenetic individuals found (data not shown). In the Oberer Arosasee, $D$ was fairly stable and lower than 0.4 throughout the year. In Unterer Arosasee, clonal diversity was lowest in late summer in both years but nearly always greater than 0.6. In Prätschsee the clonal diversity was intermediate (data not shown).

The inbreeding coefficient $\left(F_{1 S}\right)$ ranged from -0.765 to 0.439 among lakes and significant positive values of $F_{1 s}$ occurred in Murgsee, in Cadagno, and in Prätschsee both 1998 and 1999 (Fig. 5). Examined by locus, the data indicate at least two loci were responsible for significant positive $F_{1 \mathrm{~s}}$ in each of these lakes (Fig. 5). We observed outbreeding (heterozygote excess) at the Ao locus in Unterer Arosasee 1999 and in Oberer Arosasee in both 1998 and 1999 (Fig. 5). This resulted in significant negative $F_{\text {IS }}$ for all loci in the Oberer Arosasee 1998. For all populations, $F_{\text {Is }}$ for all loci was not related to proportion of sexual female, sexual male, or parthenogenetic individuals (data not shown). Genetic distance between years was highest in Prätschsee $(0.032)$ and lower in Unterer Arosasee (0.011) and in Oberer Arosasee (0.003).

\section{- Discussion}

\section{ZOOPLANKTON CHANGES OVER THE PAST 100 YEARS}

At the beginning of the 20th century many Swiss Alpine lakes were characterized and the investigators documented a diverse aquatic fauna. Since that time many of these lakes have been

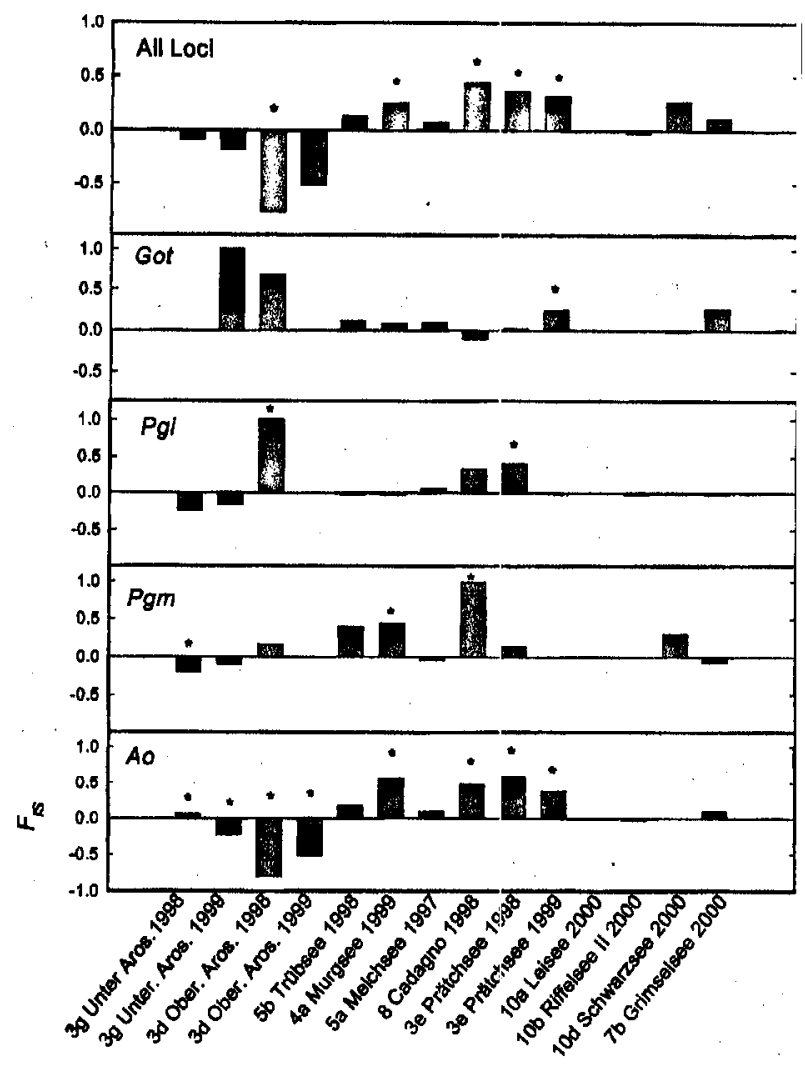

FIGURE 5. $F_{\text {IS }}$ values for each locus at each lake, including multiple years at Oberer Arosasee, Unterer Arosasee, and Prätchsee. An asterisk $\left({ }^{*}\right)$ indicates significant difference from zero. Ao $=$ Aldehyde oxidase, $P g i=$ Phosphoglucose isomerase, Got $=$ Glutamate-oxaloacetate transaminase, $P g m=$ Phosphoglucomutase.

affected by human activities (e.g., fish stocking, hydropower construction). Therefore, it is of interest to observe if the zooplankton composition has been altered in the time since these earlier studies. Because of changes to copepod and Daphnia taxonomy within the last $80 \mathrm{yr}$, comparison at species level with the former studies was problematic. We therefore made our comparisons at the genus level. Resampling of the 11 lakes did not show a drastic overall change in planktonic crustacean composition. In the Riffelsee III, the high fish density (M. Winder, pers. obs.) might explain the extinction of all planktonic crustaceans (Daphnia and Cyclops). In three other lakes, Daphnia, Cyclops, or Arctodiaptomus disappeared. Since these taxa often are preclominant during the open water period (Zschokke, 1900), they should have been detected if present even though we sampled these akes only once. In three lakes, Acanthodiaptomus or Eudiaptomus were found where previous studies did not report them.

We found large zooplankton (e.g., calanoids and daphnids) in 15 of 22 lakes where they are exposed to fish predation. In the Canadian Rocky Mountains, however, fish stocking in the 1960s resulted in the elimination of Hesperodiaptomus and Daphnia (McNaught et al., 1999), although Hesperodiaptomus can coexist with fish in lakes $>16 \mathrm{~m}$ ir depth (Donald and Anderson, 1994). We did not find such general pattern. Daphnids and calanoids coexisted with fish, even in shallow lakes such as Leisee and Älplisee, and therefore fish presence can be excluded as the general factor explaining their coccurrence or absence in these alpine lakes. The introduction of fish in Swiss Alpine lakes - also started long before the historical studies were done. Many 
Swiss Alpine lakes were stocked with juvenile lake trout in 1599 (Roth, 1971). Since then, these lakes have been stocked regularly with salmonids and/or pike. Anglers commonly introduced minnow, roach and others. Only studies of lake sediments may give more insight as to the impact fish introduction has had on zooplankton dynamics in the alpine region.

Food availability could be an important factor determining distribution of both zooplankton and fish at high elevation. For Daphnia, food availability is important for establishing a dominant population (Gliwicz, 1985) and the discriminant analyses showed that they occur in lakes with higher chlorophyll $a$ concentration (discussed below). Further, salmonids are not strictly planktivorous fish, but stomach analyses have shown that they do prey on large zooplankton (Galbraith, 1975; Fitzmaurice, 1979). Thus, the magnitude of predation pressure on zooplankton might depend on the availability of alternative food sources. In high mountain lakes some fish may live at the edge of their ecological limits, with little predatory impact on their prey. All lakes, except the Oberaarsee, are well buffered (Appendix 1), therefore acidification did not contribute to loss of species, which might be another reason for the little change in zooplankton.

Present-day zooplankton taxa diversity was unrelated to chlorophyll $a$ and POC as may have been expected if human influence was an important factor. Taxa richness decreased significantly with increasing altitude in the observed alpine lakes $(1618 \mathrm{~m}$ and 2757 $m$ a.s.1.), unlike the pattern observed by Zschokke (1900). The absence of fish also may explain the occurrence of Scapholeberis and Chaoborus-both rare in the alpine region-in the Prätschsee; however, the present study encompassed three other fishless lakes where these taxa were not found. Rotifers were the most diverse zooplankton group and were found in every lake except Grosssee. Unfortunately, comparison of past and present Rotifer data was not practicable because of missing data from the former studies. Cladocerans and copepods were often represented by only two taxa. Copepods, particularly Cyclops, occurred in almost every lake, whereas calanoids were less widespread.

\section{DAPHNIA DIVERSITY}

Daphnids were the most prevalent cladocerans, occurring in almost half of the studied lakes, and were found up to $2745 \mathrm{~m}$ a.s.l. (Riffelsee II). In the discriminant analysis, chlorophyll $a$ and POC content best separated lakes with and without Daphnia. Out of 11 lakes only Schwarzsee was not classified correctly, as it was grouped among the lakes without Daphnia. Different environmental conditions or lower susceptibility to predation might explain its occurrence there. Three Daphnia species were identified with the traditional taxonomic methods. However, daphnids are known to hybridise in nature and recent molecular analyses have revealed that lineages initially assigned to $D$. longispina or $D$. rosea were actually $D$. galeata or $D$. hyalina (Schwenk et al., 2000). In some of the observed lakes, hybrids of $D$. galeata $\times D$. rosea and $D$. galeata $\times$ D. longispina might occur (e.g., Unterer Arosasee) but are not listed here because molecular DNA analyses were not used in this study.

This study showed that the percentage of sexual Daphnia in alpine lakes can be very high (Fig. 5). The data suggest a decrease in the proportion of parthenogenetic females with in. creasing altitude. This relationship did not appear influence genetic diversity, as no relationship was observed between the proportion of sexual individuals and either clonal diversity $(D)$ or inbreeding $\left(F_{1 \mathrm{~S}}\right)$. However, the presence of multiple species and their hybrids in lakes certainly can influence levels of genetic diversity as well. The allozyme data indicate inbreeding in 4 of the 14 populations. Two of these populations were in Prătschsee (1998 and 1999), a lake with a large proportion of sexual individuals (Fig. 3), and so contrary to our initial hypothesis. Thus, it is unclear if sexual reproduction and high genetic diversity were related in these Daphnia population:s. Heterozygote excess, or outbreeding, occurred at the $A o$ locus in three populations (Oberer Arosasee 1998 and 1999, Unterer Arosasee 1999) and resulted in an overall significant negative $F_{\text {IS }}$ in Oberer Arosasee in 1998. Heterozygote excess may result from a lack of recombination in this lake where clonal diversity is low and therefore the same, possibly fixed clones, persist. Heterozygote selection is possible, although from the scope of our study it appears to occur only in these two lakes and only in 1999 for Unterer Arosasee. Scoring ersors are unlikely to occur in only 3 of 14 populations and the number and frequencies of alleles were approximately the same as other lakes (Appendix 1). What is clear is that inbreeding and outbreeding were not related to the proportion of sexual individuals in lakes, and that perhaps local processes and distinct genetic groups in individual lakes are responsible for the observed patterns. We observed genetic diversity in alpine lakes to be as high as in Swiss lowland lakes, e.g., 0.3 in Lake Lucerne, 1.4 in the Greifensee (P. Spaak, unpublished data), even though a shallow alpine lake constitutes a more homogenous habitat than a deeper lake. Whether this is a consequence of the genetic information possessed by the different species or imposed by the different habitats is not clear.

Results from the three lakes studied in multiple years provide indirect evidence that ephippia production and hatching may increase genetic diversity by creating turnover among years. In alpine lakes, more strenuous environmental conditions might favor sexual reproduction and the production of ephippial eggs. As a result, some clones may have a greater impact on the diapausing egg pool than other clones (Korpilainen, 1987). We did not study the hatching of ephippia, but the interannual genetic distance measures may provide some information regarding the hatching success of Daphnia. In the Prätschsee the Daphnia rosea population was dominated by sexual individuals, in contrast to both Oberer Arosasee and Unterer Arosasee where almost no sexual daphnids were found. More sexual individuals will mean more genetic recombination and more resting eggs that might hatch in the future. Thus we expect more genetic turnover from year to year in lakes with more sexual inclividuals. This was the case, as the genetic distance was greater botween 1998 and 1999 samples from the Prätschsee than between the same two years in the Oberer and Unterer Arosasee. This was despite Prätschsee harbouring only one morphological species (D. rosea), compared with three species in Unterer Arosasee (D. galeata, $D$. longispina, $D$. rosea). Several alternative hypotheses exist as well. The drying and re-wetting of Prătschsee may favor different genotypes in different years or may require the lake be recolonized each year. A large egg-bank also may result in lower interannual genetic diversity because similar genoty'pes return each year from the large egg reservoir of the sediments. The contribution of hatched ephippia to genetic structure in lakes within and among years requires further investigation.

We conclude that the zooplankton composition in the 11 resampled lakes has not been drastically altered in the last 100 $\mathrm{yr}$. This is despite increased human influence in some of the alpine areas studied. Fish presence can be excluded as a primary determinant of zooplankton presence or absence in these lakes. The Daphnia data suggest that the formation of resting eggs might be essential for maintaining genetic variation over time. This ability to create resting stages might also be an essential factor for the long-term persistence of other zooplankton taxa. 


\section{Acknowledgments}

We thank the many people who provided valuable assistance in the field, especially Barbara Keller, Heinz Krebs, Sandra Lass, Sven Schalla, and Anita Winder. We also thank Richard Illi, Bruno Ribi, Gabi Meier, and Silke Meyns for analyzing the water samples; Regula Illi for identifying the rotifers; and Bettina Wagner, Christine Dambone, and Barbara Keller for laboratory assistance. Sabine Giessler and Klaus Schwenk assisted with Daphnia identification. Jan Fott and Andrew Bohonac provided useful comments on an earlier version of this manuscript. This research was made possible by the EU (contract ENV4CT97-0402) within the framework of the European Commission's Environment and Climate Programme and part of the project network WATER (Wetland and Aquatic Ecosystem Research). Financial support was provided by grants from the Swiss Federal Office for Education and Science (No. 97.0040) and the Swiss National Science Foundation (No. 31-50444.97/1).

\section{References Cited}

Banta, A. M. and Brown, L. A., 1929: Control of sex in Cladocera. I. Crowding the mothers as a means of controlling male production. Physiological Zoology, 2: 80-92.

Cammarano, P. and Manca, M., 1997: Studies on zooplankton in two acidified high mountain lakes in the Alps. Hydrobiologia, 356: 97-109.

CIPRA, I. A.-K., 1998: Alpenreport-Daten, Fakten, Probleme, Lösungsansätze. Vaduz: Paul Haupt. 472 pp.

Deldon, C., Hanselmann, K., Peduzzi, R., and Bachofen, R., 1998: Orographical and geochemical description of the meromictic Alpine Lake Cadagno. Documenta Ist. ital. Idrobiol., 63: 5-9.

Donald, D. B. and Anderson, R. S., 1994: Coexistence of fish and large Hesperodiaptomus species (Crustacea: Calanoida) in subalpine and alpine lakes. Canadian Journal of Zoology, 72: 259-261.

Einsle, U, 1993: Crustacea, Copepoda, Calanoida und Cyclopoida. Süsswasserfauna von Mitteleuropa. 8/4-1. Stuttgart. 208 pp.

Emmenegger, L., 1999: Light-induced redox cycling of iron in lakes, Ph.D. thesis, ETH, Zürich. $112 \mathrm{pp}$.

Fitzmaurice, P., 1979: Selective predation on Cladocera by brown trout Salmo trutta. Journal of Fish Biology, 15: 521526.

Flößner, D., 1972: Kiemen- und Blattfußßer, Branchiopoda Fischläuse, Branchiura. In Dahl, F (ed.), Die Tierwelt Deutsch lands. Jena: Gustav Fischer Verlag. 499 pp.

Flößner, D., 1993: Zur Kenntnis einiger Daphnia-Hybriden. Limnologica, 23: 71-79.

Flößner, D. and Kraus, K., 1986: On the taxonomy of the Daphnia hyalina-galeata complex (Crustacea: Cladocera). Hydrobiologia, 137: 97-115.

Galbraith, M. G., 1967: Size-selective predation on Daphnia by rainbow trout and yellow perch. Transactions of the American Fisheries Society, 96: 1-10.

Gießler, S., Mader, E., and Schwenk, K., 1999: Morphological evolution and genetic differentiation in Daphnia species complexes. Journal of Evolutionary Biology, 12: 710-723.

Gliwicz, Z. M., 1985: Predation or food limitation: an ultimate reason for extinction of planktonic cladoceran species. Archiv fur Hydrobiologie, Beiheft Ergebnisse der Limnologie, 21: $419-430$.

Hebert, P. D. N., 1974: Ecological differences between genotypes in a natural population of Daphnia magna. Heredity, 33: 327-337.

Hebert, P. D. N, and Beaton, M. J., 1989: Methodologies for Allozyme Analysis Using Cellulose Acetate Electrophoresis. Beaumont, Texas: Helena Laboratories. $32 \mathrm{pp}$.

Hedrick, P. W., 1986: Genetic polymorphism in heterogenous environments: A decade later, Annual Review of Ecolology and Systematics, 17: 535-566.

Korpelainen, H., 1987: Reproductive strategies of Daphnia magna genotypes. Hereditas, 106: 181-138.

Koste, W., 1978: Rotatoria: die Rädertiere Mitteleuropas: ein Bestimmungswerk begründet von Mcx Voigt; I Textband, II Tafelband. Berlin: Gebrüder Borntraeger. I 673 pp; II 234 pp.

Kreis, H. A., 1921: Die Jöriseen und ihre postglaziale Besiedelungsgeschichte. Internationale Revue der gesamten Hydrobiologie und Hydrographie, 9: 189-2.12.

Lieberman, D. M., 1993: Aquatic ecology studies of twin lakes, Colorado 1971-86: Zooplankton. Engineering and science monograph, 43: 113-122.

Margaritora, F., 1983: Cladoceri (Crustacea: Cladocera). Consiglio Nazionale della Ricerche, 22: 1-169.

McNaught, A. S., Schindler, D. W., Parker, B. R., Paul, A. J., Anderson, R. S., Donald, D. B., and Agbeti, M., 1999: Restoration of the food web of an alpine lake following fish stocking. Limnology and Oceanography, 44: 127-136.

Medina-Sánchez, J. M., Villar-Argaiz, M., and Sánchez-Castillo, P., 1999: Structure changes in a planktonic food web: biotic and abiotic controls. Journal of Limnology, 58: 213-222.

Müller, R., 2000: Personal communication. Swiss Federal Institute for Environmental Sciences and Technology (EAWAG), Limnological Research Center, CH-6(147 Kastanienbaum.

Nei, M., 1978: Estimation of average heterozygosity and genetic distance from a small number of individuals. Genetics, 89: 583-590.

Pesta, O., 1929: Der Hochgebirgssee der Alpen. Die Binnengewässer. Stuttgart: E. Schweizerbart'sche Verlagsbuchhandlung. $156 \mathrm{pp}$.

Raymond, $M$. and Rousset, F, 1995: GENEPOP (version 1.2): population genetics software for exact: tests and ecumenicism. Journal of Heredity, 86: 248-249.

Rosenzweig, M. L., 1995: Species Diversity in Space and Time. Cambridge: Cambridge University Press. 436 pp.

Roth, H., 1971: Die fischereiliche Bewirtung von Bergseen und Baggerseen. Veröffentlichungen des Eidgenössischen Amtes für Umweltschutz und Eidgenössischen Fischereiinspektion, 28: 1-8.

Schwenk, K., Posada, D., and Hebert, P. D. N., 2000: Molecular systematics of European Hyalodaphnia: the role of contemporary hybridization in ancient species. Proceedings of the Royal Society of London Series B Biological Sciences, 267: 1833-1842.

Schwenk, K. and Spaak, P., 1995: Evolutionary and ecological consequences of interspecific hybridization in cladocerans. $E x$ perientia, 51: 465-481.

Sokal, R. R. and Rohlf, F. J., 1995: Biometry. San Francisco: Freeman. 887 pp.

Stingelin, T., 1904: Unser heutiges Wissen uber die Systematik und die geographische Verbreitung der Cladoceren. Extrait des Comptes rendus du 6me Congres international de Zoologie, 6: 533-541.

Stingelin, T., 1910: Crustaceen aus kleineren Seen der Unterwaldner und Berneralpen. Revue suisse de Zoologie, 18: 107172.

Straskrabová, V., Callieri, C., Carrillo, P., Cruz-Pizarro, L., J., F, Hartman, P., Macek, M., Medina-Sánchez, J. M., Nedoma, J., and Simek, K., 1999: Investigations on pelagic food webs in mountain lakes-aims and methods. Journal of Limnology, 58: $77-87$.

Swofford, D. L. and Selander, R. B., 1981: BIOSYS-1: a fortran program for the comprehensive analysis of electrophoretic data in population genetics and systematics. Journal of Heredity, 72: 281-283.

Taylor, D. J., Hebert, P. D. N., and Colbourne, J. K., 1996: Phylogenetics and evolution of the Daphnia-longispina group (crustacea) based on 12s rDNA sequence and allozyme variation. Molecular Phylogenetics and Evolution, 5: 495-510. 
Tockner, K., Malard, F., Burgherr, P., Robinson, D. T., Uehlinger, U., Zah, R., and Ward, J. W., 1997: Physico-chemical characterization of channel types in a glacial floodplain ecosystem (Val Roseg, Switzerland). Archiv für Hydrobiologie, 140: 433463.

Zschokke, F, 1900: Die Tierwelt der Hochgebirgsseen. Neue
Denkschriften der schweizerischen naturforschenden Gesellschaft. $400 \mathrm{pp}$.

Zschokke, F, 1908: Die Resultate der zoologischen Erforschung hochalpiner Wasserbecken seit dem Jahre 1900. Internationale Revue der gesamten Hydrobiologie und Hydrographie, Leipzig: Werner Klinkhardt Verlag. 235 pp. 
APPENDIX 1

Site overview and lake characteristics

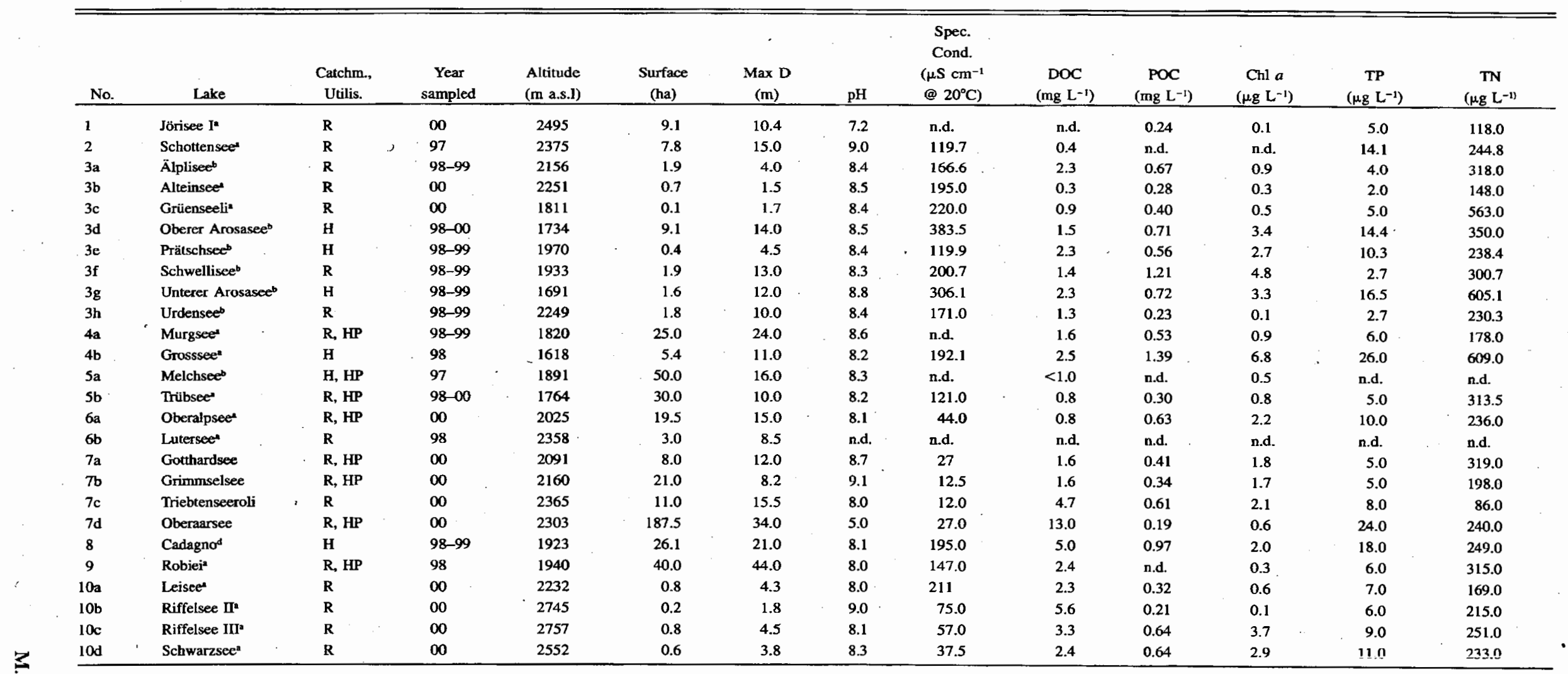

$\mathrm{DOC}=$ dissolved organic carbon, $\mathrm{POC}=$ particulate organic carbon, Chl. $a=$ Chlorophyll $a, \mathrm{TP}=$ total phosphorus, and TN $=$ total nitrogen, ${ }^{\mathrm{p}} \mathrm{pH}, \mathrm{Spec} . \mathrm{Cond}, \mathrm{DOC}, \mathrm{POC}, \mathrm{Chl}$ a, TP, and TN are the mean values for the water profile in late summer/early autumn, ${ }^{b} \mathrm{pH}$, Spec. Cond, DOC, POC, Chl a, TP, and TN are the mean values for the water profile during the open water period, c Values for Melchsee are from Emmenegger (1999), ${ }^{d}$ Values for Lake Cadagno are from Deldon et al. (1998), $\mathbf{R}=$ Remote catchment, $\mathbf{H}=$ widely infuenced by Human activities, HP $=$ used for Hydropower Production, n.d. $=$ not determined. 